\title{
Additions to the Plymouth Marine Fauna (1931) in the Crustacean Orders Tanaidacea, Isopoda and Amphipoda.
}

By

\author{
G. I. Crawford, \\ Former Student Probationer at the Plymouth Laboratory.
}

With I Figure in the Text.

This list contains 2 species of Tanaidacea, 6 of Isopoda and 28 of AмгнIтоDA. These were all collected by myself in 1934-5, with the exception of 3 species of Amphipoda, which have not been entered in the Plymouth list although accounts of their capture at Plymouth have been published. These are Eusirus longipes Boeck, recorded by Hunt (1924); Gammarellus angulosus (Fabr.), by Kitching, Macan and Gilson (1934); and Gammarus zaddachi Sexton, by Serventy (1935).

The list is drawn up in the systematic order adopted in Plymouth Marine Fauna (1931), with a reference to a good illustration of each species. The dates and circumstances of capture are stated, and when a species has already been recorded from off the coasts of Devon and Cornwall by Norman and Scott (1906) a note to that effect has been made. The distribution is not stated, since recent accounts of the distribution of every species are available in the following works :

Tanaidacea and Isopoda: Nierstrasz and Stekhoven, 1930 (except for Synisoma acuminatana, q.v.).

Amphipoda : Chevreux and Fage (1925) or Stephensen (1929).

All the Amphipod species in this list are included in one or other of these publications, and almost all in both.

Every species has been referred to a specialist for identification. Tanaidacea and Eurydice truncata and Gnathia oxyuraca to J. H. Schuurmans Stekhoven of Utrecht; the other Isopoda to Prof. W. M. Tattersall of Cardiff; the Amphipoda to Dr. K. Stephensen of Copenhagen, excepting Gammarus zaddachi Sexton, which Mrs. Sexton herself has named. A complete set of the specimens named by these experts has been given to the Museum at the Plymouth Laboratory, and specimens of a number of species are in the British Museum (Nat. Hist.). 


\section{Order TANAIDACEA}

\section{Family Tanaidæ.}

Tanais chevreuxi Dollfus [Dollfus, 1897, p. 36]

28-6-34. Looe; about 30 specimens making burrows in the silt in erevices of shale from about half-tide downwards.

5 4-35. Wembury; in similar situations, a few 우 only.

As far as my collecting experience goes the habitat of this species is quite distinct from that of the far commoner T. cavolini M. Edw. I have found $T$. chevreuxi nowhere but in shale crevices; and $T$. cxvolini very commonly in old borings of Limnoria in Millbay West Wharf, and in burrows, apparently of its own making, in the felting of sandgrains formed round a red alga (Polysiphonia sp.) on rocks near high-tide mark (Salcombe, Wembury, Rum Bay).

\section{LePtognathia GRACIlIOIDES (Lilljeborg) [Nierstrasz and Stekhoven,} 1930 , p. 152]

16-5-35. 1 mile S. from Plankton Station L3, 20-25 fm., 5 우.

6-7-34. Cawsand Bay, 3-5 fm., 5 우.

The best account of the boreal species of Leptognathia is given by Hansen (1913, pp. 65 et seq.). According to him L. gracilioides has been confused with three other species, all more northerly in distribution: namely $L$. gracilis Kröyer, $L$. sarsii Hansen and $L$. longiremis Lilljeborg, all of which he figures. The figures labelled L. longiremis in Sars (1885) and Sars (1896) are said by Hansen to refer to L. gracilis and L. sarsii respectively. L. gracilioides has never been figured, so I have drawn the cheliped of $\mathrm{a}$ ㅇ from the locality south of L3 (Fig. 1).

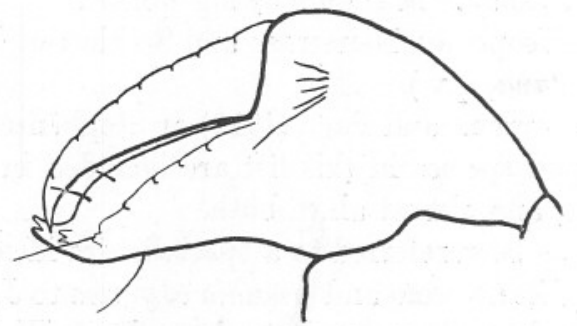

FıG. 1.-Leptognathia gracilioiles, cheliped of $\supsetneq, \times 190$.

The thumb is bifid at the tip and smooth along the anterior edge. On its outer surface it bears a longitudinal tuberculated ridge. All my specimens agree in these respects.

In the other three species the thumb is single at the tip, and the distal part of the anterior edge bears four or five sharp serrulations. Tubercles are present on the thumb in $L$. sarsii, though not in $L$. gracilis and $L$. 
longiremis, but this species is easily distinguished by the presence of a triangular projection on the lower lateral edge of the last abdominal segment, which is absent in all the other three species. This is well shown in the figures of Sars (1896).

\section{Order ISOPODA}

\section{Sub-Order FLABELLIFERA \\ Family Anthuridæ}

Cyathura Carinata (Kröyer) [Norman and Stebbing, 1886, p. 124]

1-8-34. R. Lynher, Wivelscombe Lake; 1 specimen in "salting cliff" (apparently an unusual locality).

6-6-35. R. Lynher, opposite Sconner Creek ; 6, in mud.

3-7-35. R. Tavy, Maristow Ford; 8, in mud on R. bank.

There is little doubt that the specimens from Tamar mud-flats recorded by Percival (1929, p. 102) as Anthura gracilis (Montagu), and entered as such in Plymouth Marine Fauna (1931), are really Cyathura carinata, though they are not available for examination. Anthura gracilis is usually found in dredgings of stone and weed, and scarcely enters brackish water.

Cyathura carinata has been recorded in English estuaries in Norfolk by Gurney (1907), Suffolk by Serventy (1935), and Hampshire by OmerCooper (1916). I have also found it in the Exe and Taw (Devon). Apparently it is common and widely distributed in England.

\section{Family Gnathiidæ}

GNathia OXYurAa (Lilljeborg) [Monod, 1926, p. 538]

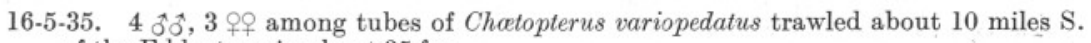
of the Eddystone in about $35 \mathrm{fm}$.

Recorded by Norman and Scott (1906) from near Starcross, S. Devon, in 5 fathoms.

\section{Family Cirolanidæ}

Cirolana borealis Lilljeborg [Sars, 1897, p. 70]

25-10-34. Mallard Buoy, Sound, 1 dredged.

4-12-34. Melampus Buoy, Sound, 1 dredged.

Recorded by Norman and Scott (1906) as rare off Devon coast.

Eurydice truncata (Norman) [Norman, 1868, p. 421]

4-9-34. Eddystone Shell Gravel, 2 dredged.

Recorded by Norman and Scott (1906) off Prawle Point, Devon. NEW SERIES.-VoL. XXI. No. 1. November, 1936. 


\section{Sub-Order VALVIFERA}

\section{Family Idoteidæ}

IDoteA viRIDIs (Slabber) [Sars, 1897, p. 83, as I. viridis; Plate 34 as

\section{I. angusta]}

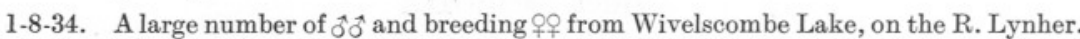
31-5-35. The same locality, common among Ulva in salting pools.

The species is also common among the Zostera in St. John's Lake, according to T. G. Tutin who has brought me back specimens.

Sars states that the colour is uniformly greenish. A large proportion of the living specimens that I have seen are dark greenish brown or clear green dotted with black.

Synisoma acuminatana Leach [Dollfus, 1894, p. 5]

5-4-35. Wembury Bay West, about 12 specimens washed from Halidrys siliqua in a large

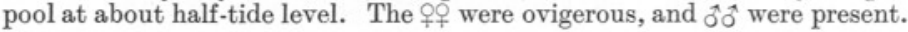

These were kept alive for two months in the Laboratory where they fed voraciously on Halidrys. At rest they ranged themselves along the stalks or vesicles, and showed such resemblance to the vesicles in colour, form and size, that they were difficult to distinguish.

According to Norman and Scott (1906) this species has been recorded from Devonshire by Leach, and Cornwall (Falmouth) by Cocks.

Distribution. Mediterranean and Adriatic, Black Sea, S. British coasts to Cumbrae on the Clyde, Channel Isles. Collinge (1917, p. 752).

\section{Family Lyssianassidæ}

LepidepeCreum Longicorne (Bate and Westwood) [Chevreux and Fage, 1925, p. 63]

17-10-34. Cawsand Bay, D.-net, 1 ㅇ.

1-2-35. Tow-nets, 1 juvenile.

19-2-35. Ring-trawl, 2 우.

The specimens in the tow-nets and ring-trawl were attached to pieces of hydroid, and had probably been brought up from the bottom by rough weather.

\section{Family Ampeliscidæ}

Ampelisca diadema (A. Costa) [Chevreux and Fage, 1925, p. 82]

I have dredged this species rather commonly, on mixed grounds with a high silt content, in 20-25 fathoms. A tenuicornis Lilljeborg was found, usually in much greater numbers, in the same hauls. No doubt this name has frequently been applied to both species. 


\section{Family Argissidæ}

Argissa stebbingi J. Bonnier [Chevreux and Fage, 1925, p. 90]

17-10-34. Cawsand Bay ; $1 \hat{\jmath}, 1$ ㅇ with eggs.

29-11-34. Middle Sound; 2 우 with eggs.

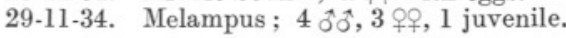

Dr. Stephensen writes, " Though eyes are present, I have referred the specimens to this species, for the hind corner of 3rd metasome segment is rounded (as in Chevreux and Fage, 1925, fig. 82), not somewhat quadrate as in A. hamatipes (G. O. Sars, 1894, pl. 48) (but Bonnier (1896) says that this corner is ' à peu près droit '). Nevertheless I have not been able to find other or more valid specific characters."

The presence or absence of eyes cannot be considered as a specific character in our present state of knowledge of these two species, since Chevreux and Fage state of $A$. Stebbingi, "Yeux formés de 4 à 8 cristallins disposés en carré (aveugle dans les grands fonds)."

Argissa hamatipes (Norman) is recorded by Norman and Scott (1906) off Exmouth.

\section{Family Haustoriidæ}

Urothö̈ Grimaldi Chevreux, var. PoseIdonis Reibisch. [Reibisch, 1905 , p. 163 ; Chevreux and Fage, 1925, p. 100, as var. inermis]

This species is common in clean sand at low-water springs on the east side of the river at Salcombe, just south of Millbay. It burrows to a depth of $8-12$ inches at low tide.

This ground is full of Echinocardium cordatum and Acrocnida brachiata. Urothoë showed a pronounced tendency to live in the burrows of Acrocnida.

Found commonly, on 6-3-35, 4-4-35 and 2-5-35.

Urothö̈ BREVICORnIs Bate [Chevreux and Fage, 1925, p. 100]

21-8-1900. D-net on the Bar, Salcombe, 2 우우 (in Plymouth Laboratory Museum).

5-11-34. Dredged, Whitsand Bay, one in 3-5 fm., in 1 haul.

16-11-34. Dredged, Whitsand Bay, 19, in 3-5 fm., in 6 hauls.

7-3-35. Drake's Island, 1 in sand at extreme low-water springs.

The sand in Whitsand Bay is similar to that at Salcombe in which $U$. grimaldii var. poseidonis occurs. That is to say when graded by the sieves specified by Allen (1899), it contains about $95 \%$ of fine sand and 0.3 to $0.5 \%$ silt.

In seven hauls taken on similar sand in Bigbury Bay no Urothoë was found.

Recorded by Norman and Scott (1906) from Goodrington Sands. 
Urothö̈ elegans Bate [Chevreux and Fage, 1925, p. 101]

16-5-34. 1 mile S. of Plankton Station L3 ; 2 우.

6-7-34. Cawsand Bay; 3 ऊิô, 4 우우.

14-8-34. Sand near Eddystone, $28 \mathrm{fm}$.; 1 ㅇ․

3-10-34. Rame-Eddystone, 25-27 fm.; 4 (2 hauls).

17-10-34. Cawsand Bay; D-net, 2.

1-11-34. Cawsand Bay; 1 .

29-11-34. Melampus, Plymouth Sound; D-net, 1.

29-11-34. Melampus; 19.

12-4-35. White patches, Plymouth Sound, 1.

With two exceptions all these collections were made with the finemeshed dredge.

This is the smallest of the four local species and lives in finer and siltier sand than any of the others. The soil of Cawsand Bay contains $78 \%$ of fine sand and $19 \%$ of silt, and the soil at Melampus is a mixture of a similar silty sand with large stones. The largest of the four local species is $U$. marina (Bate) which lives in coarse sand or fine gravel (e.g. some parts of the Eddystone shell-gravel area).

Recorded by Norman and Scott (1906) in tow-nettings off the north and south coasts of Cornwall.

\section{Family Amphilochidæ}

Amphilochus spence-BateI (Stebbing) [Chevreux and Fage, 1925, p. 115]

29-11-34. Melampus; D.-net, 2.

29-11-34. Asia Shoal; D.-net, 6.

\section{Family Leucothoidæ}

Leucothö̈ INCISA D. Robertson [Chevreux and Fage, 1925, p. 123]

30-3-33. Eddystone; stramin-net, 1 o . Collected by F. S. Russell.

Leucothö̈ LILlJeborgi Boeck [Chevreux and Fage, 1925, p. 124]

14-8-34. Rame mud, 20-25 fm.; 13.

Besides these a number of juvenile or incomplete specimens belonging possibly to one or other of these species were taken in Cawsand Bay, New Grounds, Melampus, Bigbury Bay and the Eddystone Grounds.

Also among tubes of Chotopterus variopedatus trawled 6-10 miles south of the Eddystone, ten specimens were obtained on 16-5-35, and six on 23-9-35, of a large undescribed species of Leucothoë.

\section{Family Stenothoidæ}

Parametopa kervillei Chevreux [Chevreux and Fage, 1925, p. 138]

7-10-34. Cawsand Bay; D.-net, 1 i with eggs. 


\section{Family Acanthonotozonidæ}

Panoploea eblane (Bate) [Chevreux and Fage, 1925, p. 149]

1-2-35. Tow-nets, 1 .

\section{Family Calliopiidæ}

Calliopius crenulatus Chevreux and Fage [Chevreux and Fage, 1925, p. 183]

6-3-35. Salcombe; washed from Cystosira sp. just below extreme low-water springs, 1 ㅇ with eggs.

I have found C. laeviusculus (Kröyer) in rock-pools near low-water at Treyarnon Bay on the coast of North Cornwall, and Norman and Scott (1906) record it from Exmouth and Teignmouth Bay under the name of C. rathkei (Zaddach). No doubt this species exists also in the Plymouth area. Stephensen (1931, pp. 282-286) gives reasons for considering these two names synonymous.

\section{Family Pleustidæ}

Stenopleustes Malmgreni (Boeck) [ G. O. Sars, 1894, p. 355]

26-7-34. Metre-net, 6 miles S. of Rame Head, 2.

2-8-34. Metre-net, 2.

22-10-34. Tow-nets, 1 ㅇ with eggs (3 mm. long).

14-2-35. Tow-nets, 1 ㅇ with eggs (4 mm. long).

19-2-35. Ring-trawl, 1 o with eggs.

These specimens were probably brought up from the bottom by rough weather.

Sars (1894) described his specimens, which came from deeper water (80-150 fathoms) and from further north, as colourless. Mine were quite brightly coloured (e.g. specimen of 14-2-35 described from life) :

"Eyes : red pigment lying deep in the centre, circumference and surface colourless. Antenna: colourless and transparent, except for the two basal joints which are strawy-brown; distal end of joints ringed with red-brown dots. Body: colourless, with much underlying strawy-brown pigment, and a few superficial red-brown or orange-brown dots."

My adult 우 measured only $4 \mathrm{~mm}$., whereas his were $7 \mathrm{~mm}$. long.

\section{Family Eusiridæ}

Eusirus LongIPEs Boeck [Chevreux and Fage, 1925, p. 201]

14-8-34. Rame mud; 1 specimen $4.5 \mathrm{~mm}$. long.

14-8-34. Rame, Turitella ground; 1 specimen $10 \cdot 5 \mathrm{~mm}$. long with eggs, 1 specimen $9 \mathrm{~mm}$. long.

This species was first found off Plymouth by O. D. Hunt (1924, p. 580), but it has not been included in Plymouth Marine Fauna. 


\section{Family Gammaridæ}

Gammarellus angulosus (Rathke) [Chevreux and Fage, 1925, p. 204]

Wembury Bay, identified by G. A. Steven. See Kitching, Macan and Gilson (1934, p. 699).

Recorded as Amathilla homari by Norman and Scott (1906) from Torquay and Ilfracombe (Devon), and Falmouth, Fowey and Polperro (Cornwall).

Gammarellus homari (Fabricius) [Chevreux and Fage, 1925, p. 205]

6-3-35. Salcombe. Washed from Cystosira sp. just below extreme low-water springs. 4 immature specimens.

Melita Pellucida G. O. Sars [Chevreux and Fage, 1925, p. 228]

Occurs in a few streams running into the Tamar and Tavy.

13-6-35. R. Tamar, stream through Haye, about $2 \mathrm{~m}$. below Calstock bridge ; abundant. 3-7-35. R. Tavy, stream at Lopwell; common.

do. Lopwell ferry, in channel; a few.

do. Blaxton creek, in channel; a few.

In all these localities Gammarus chevreuxi Sexton and G. zaddachi Sexton also occurred abundantly. All were in water of low salinity. At Lopwell Ferry and in Blaxton Creek the salinity rises considerably at high tide ; but the other two streams are separated from the main current by valves, and the water must always be nearly fresh.

I have also found this species in the Exe (S. Devon), Taw (N. Devon) and Benfleet Creek (Essex) in similar situations. The only other English locality known for this species is Norfolk, Gurney (1907).

Gammarus zadDachi Sexton [Sexton, 1912, p. 657]

In March, 1934, a number of specimens of $G$. zaddachi were found in the River Tamar among Fucus at Pentillie Quay, Haldon Quay, and Whitsam by Serventy (1935), who also records the species from Suffolk and Norfolk.

In $1935 \mathrm{I}$ found it to be the commonest brackish-water Gammarus in the Tamar, Tavy and Lynher. It was common in nearly every stream running into these rivers that I investigated, and in the upper tidal reaches of the Tavy from Mount Jessop Ford to Lopwell Ferry.

Percival (1929) in his report on these estuaries does not record it, including it probably under G. locusta or G.duebeni.

I have also found it in brackish water in the Camel (N. Cornwall), Exe (S. Devon), Taw (N. Devon), Frome (Wareham, Dorset), Avon (Tewkesbury, Gloucestershire), Towy (S. Wales). 


\section{Family Dexaminidæ}

Dexamine thea Boeck [Chevreux and Fage, 1925, p. 265]

This species is common among weeds, and roots of Laminaria near lowwater mark on the rocks below the Laboratory. I have also found it at Looe, at Wembury and on the Salstone.

Recorded by Norman and Scott (1906) from Exmouth, Dartmouth, Falmouth.

\section{Family Talitridæ}

Hyale Perieri (Lucas) [Chevreux and Fage, 1925, p. 284]

12-4-35. Gara Point among Nucella lapillus on an exposed headland; 4.

These specimens include an adult ô and a o + with eggs ; owing to their small size ( $c a .4 \mathrm{~mm}$.) Dr. Stephensen has tentatively included them under var. minor Chevreux and Fage. Some specimens which I collected in exposed situations on the North Cornish Coast at Trevose Head, Treyarnon Bay and Trevarrian are larger than these, and agree in size with the species $H$. perieri as described by Chevreux and Fage.

Two other Hyale species are present on the S. Devon coast. H. nilssoni (Rathke) is very common intertidally in areas which are moderately or very sheltered (e.g. Plymouth Breakwater, Wembury, Looe, Tamar Estuary to beyond Saltash). H. pontica (Rathke) has so far only been found near low-tide mark on the Breakwater-a position apparently intermediate in exposure between those inhabited by the two other species.

\section{Family Photidæ}

Gammaropsis nana G. O. Sars [Sars, 1894, p. 561]

29-11-34. Melampus; D.-net, 1 ô, 1 ㅇ‥

29-11-34. Asia Shoal; D.-net, 6 우.

18-2-35. Tow-nets, 1 of, 3 우․

19-2-35. Ring-trawl 1 ‥

Stebbing (1906) and Chevreux and Fage (1925) considered this species the same as Eurystheus palmatus (Stebbing and Robertson) [Chevreux and Fage, 1925, p. 313]. But Dr. Stephensen advises me to record it under Sars' name, believing the species to be possibly distinct. The 2nd gnathopod of the $\hat{o}$ is slightly different.

Podoceropsis sophiæ Boeck [Chevreux and Fage, 1925, p. 316]

4-5-34. Mewstone Grounds ; 1 on Maia squinado.

16-5-34. I mile S. of Plankton Station L3; 1 , 6 웅․

18-7-34. Mixed grounds off breakwater light, $23 \mathrm{fm} . ; 1$ ô, 1 ㅇ.

2-8-34. Metre-net (rough weather); 1 ô, 3 웅.

3-10-34. Rame-Eddystone, $27 \mathrm{fm} . ; 1$ \%.

22-10-34. Tow-nets, 1 .

18-2-35. Tow-nets, 1 ô, 3 우우.

This species is quite common on mixed grounds with much silt. Recorded by Norman and Scott (1906) from Start Bay. 
Leptocheirus PILosus Zaddach [Chevreux and Fage, 1925, p. 322]

29-1-35. Neille Point, R. Tamar ; one.

2.8-35. Whitsam, R. Tamar, several among Cordylophora lacustris.

9-8-35. Chelson Meadow in ditches near sluice ; several building nests on Ruppia marina

3-9-35. Calstock Bridge and Ashburton Turn, R. Tamar ; abundant among Cordylophora lacustris.

I have also found this species in similar situations in the Exe (S. Devon), Taw (N. Devon) and Towy (S. Wales). It is recorded from Suffolk by Serventy (1935) and from Norfolk as Leptocheirus sp. by Gurney (1907).

LePtocheirus Pectinatus Norman [Cherreux and Fage, 1925, p. 324]

3-10-34. Rame-Eddystone, 25 fms.; 2 우우.

29-11-34. New grounds, Plymouth Sound; 1 ‥

A third species, Leptocheirus guttatus (Grube), is recorded from Falmouth harbour by Norman and Scott (1906), and probably is also present at Plymouth.

\section{Family Amphithoidæ}

Амрнітнов̈ vaILlanti Lucas [Chevreux and Fage, 1925, p. 333]

6-7-34. Cawsand Bay; 36.

9-8-34. New grounds; 2.

14-8-34. Near Drake's Island; 1.

11-10-34. Mouth of R. Yealm ; 9.

18-10-34. Winter Shoal; 32.

2-11-34. Rame mud (20-25 fm.); 3, on a Maia squinado.

29-11-34. Middle Sound; 2.

7-12-34. Winter Shoal; 1.

With one exception (noted above) all these collections were made ámong algæ in sheltered shallow water $(3-10 \mathrm{fm}$.). No doubt this species has frequently been confused with $A$. rubricata (Montagu) which is rather commoner in similar situations, and in addition occurs between tide marks.

\section{Family Corophiidæ}

Corophium acutum Chevreux [Chevreux and Fage, 1925, p. 366]

Very common among algæ, sponges and Laminaria roots just above and below low-water springs, along the fringes of Plymouth Sound; common among sponges on West Wharf and the Pontoon, Millbay Docks.

Corophium ACherusicum Costa [Chevreux and Fage, 1925, p. 368]

Very ccmmon on buoys and rafts in Plymouth Sound and the Hamoaze : 'Tinside bathing raft, buoy off Trevol Quay St. John's Lake, buoys at junction of Tamar and Lynher, Neille Point buoys. 


\section{Sub-order HYPERIIDEA}

\section{Family Hyperiidæ}

Hyperoche medusarum Kröyer [Chevreux and Fage, 1925, p. 405, as H. kröyeri Bovallius]

29-1-35. Tow-nets, 1 ㅇ with eggs.

20-3-35. Tow-nets, 1 오.

4-4-35. Ring-trawl, 1 ô.

The synonymy of this species is elucidated by K. Stephensen (1923, p. 13). From his summary of records of its occurrence it appears that Plymouth lies on the extreme south-eastern limit of its range.

\section{ACKNowledgements.}

I wish to express my warmest thanks to Dr. Stephensen, Dr. Stekhofen, Prof. Tattersall and Mrs. Sexton for their help in identification : to Dr. Allen for his encouragement and advice: and to the boat-staff of the Plymouth Laboratory for their help in collecting.

\section{REFERENCES.}

Allen, E. J. 1899. On the Fauna and Bottom-Deposits near the Thirty Fathom Line from the Eddystone Grounds to Start Point. Journ. Mar. Biol. Assoc., N.S., Vol. V, pp. 365-542.

Bonnier, J. 1896. Résultats Scientifiques de la Campagne du "Caudan " -Edriophthalmes. Ann. Univ. Lyon, III, pp. 527-689.

Chevreux, E., and FAge, L. 1925. "Amphipodes" in "Faune de France." 9, pp. 1-488.

Collinge, W. E. 1917. A revision of the British Idoteidæ, a Family of Marine Isopoda. Trans. Roy. Soc. Edinb., Vol. LI, pp. 721-760.

Dollfus, A. 1894. Les Idoteidæ des Côtes de France. Feuill. jeun. Nat. 289 , pp. 1-5.

1897. Campagnes de la Melita. Tanaidæ récoltés par M. Ed. Chevreux dans L'Atlantique et dans la Méditerranée. Mém. Soc. Zool. Fr., XI, pp. 35-47.

Gurney, R. 1907. The Crustacea of the East Norfolk Rivers. Trans. Norfolk Norw. Nat. Soc. Vol. VIII, pp. 410-438.

Hansen, H. J. 1913. Danish Ingolf Exped. III. 3. Crustacea Malacostraca. 2. Tanaidacea, pp. 1-145.

Hunt, O. D. 1924. The Food of the Bottom Fauna of the Plymouth Fishing Grounds. Journ. Mar. Biol. Assoc., N.S., Vol. XIII, pp. 560598.

Kitching, J. A., Macan, T. T., and Cary Gilson, H. 1934. Journ. Mar. Biol. Assoc., N.S., Vol. XIX, pp. 677-706. 
Monod, T. 1926. Les Gnathiidæ. Essai Monographique. Mém. Soc. Sci. Nat. Maroc., XIII, pp. 1-668.

Nierstrasz, H. F., and Stekhoven, J. H. S. 1930. “ "Die Tierwelt der Nord- und Ostsee." Leif. XVIII. Teil X. $\mathrm{e}_{2}$. Isopoda genuina. $\mathrm{e}_{3}$. Anisopoda, pp. 33-172.

Norman, A. M. 1868. On two Isopods, belonging to the genera Cirolana and Anilocra, new to the British Isles. Ann. Mag. Nat. Hist., Ser. 4, Vol. 2, pp. 421-22.

Norman, A. M., and Scott, T. A. 1906. Crustacea of Devon and Cornwall. London, pp. 53-99.

Norman, A. M., and Stebbing, T. R. R. 1886. On the Crustacea Isopoda of the "Lightning," "Porcupine," and "Valorous" Expeditions. Trans. Zool. Soc. Lond., XII, pp. 77-141.

OMer-Cooper, W. 1916. On some undescribed features in the structure of Cyathura carinata (Kröyer). Journ. Zool. Research, I, 3, pp. 97101.

Percival, E. 1929. A Report on the Fauna of the Estuaries of the River Tamar and the River Lynher. Journ. Mar. Biol. Assoc., N.S., Vol. XVI, pp. 81-108.

Plymouth Marine Fauna, 1931. 2nd Ed., pp. 181-198.

ReIBISCH, J. 1905. Faunistisch-biologische Untersuchungen über Amphipoden der Nordsee. Wiss. Meeresuntersuch. Kiel, VIII, pp. 147-188.

Sars, G. O. 1885. Nordske Nordhavs Exped. Crustacea I, pp. 1-280. 1894. Crustacea of Norway. I. Amphipoda, pp. 1-711. 1896-9. Crustacea of Norway. II. Isopoda, pp. 1-270.

Serventy, D. L. 1935. Ojservations on Gammarus zaddachi Sexton, an Estuarine Amphipod, and Associated Forms. Int. Rev. Hydrobiol., XXXII, pp. 285-294.

Sexton, E. W. 1912. Some Brackish-water Amphipoda from the mouths of the Weser and the Elbe, and from the Baltic. Proc. Zool. Soc. London, pp. 656-665.

Stebbing, T. R. R. 1906. Das Tierreich XXI. (1) Amphipoda. I. Gammaridea, pp. 1-806.

Stephensen, K. 1923. Danish Ingolf Exped. III. 8. Crustacea Malacostraca 5. Amphipoda 1. pp. 1-100.

— 1929. "Die Tierwelt der Nord- und Ostsee." Leif XIV. Teil X. f. Amphipoda, pp. 1-188.

1931. Danish Ingolf Exped. III. 11. Crustacea Malacostaca 7. Amphipod 3, pp. 177-290. 